\title{
EFEKTIVITAS PENDEKATAN KOMUNIKATIF PADA MATA KULIAH MENYIMAK DAN BERBICARA II
}

\author{
Timur Sri Astami; Rosita Ningrum; Felicia Budihardja
}

Japanese Department, Faculty of Humanities, Bina Nusantara University

Jln. Kemanggisan Ilir III, No. 45, Kemanggisan-Palmerah, Jakarta Barat 11480

timur_astami@yahoo.com; ningrum@binus.edu; fbudihardja@binus.edu

\begin{abstract}
The previous research on Communicative Approach in language learning stated that there was a correlation between speaking and writing abilities, in which both of them belong to productive skill. By presenting effective results, the students'speaking skills could be developed. Based on that previous result, this research was focused on between the receptive and productive knowledge, those were listening and speaking, especially on the respondents who were the beginners to know to what extent the level of their speaking competences. The research applied quasi experiment method without having control class to describe a learning process by applying communicative approach. Respondents were the second semester of Japanese department students, year 2012/2013. The research data was taken twice, in the pre-test and post-test time, as well as questionnaires to know the respondents' results on the learning process. The results indicated that the average increase of class respondents' achievement was 16.31 point, that was from 66.84 of pre-test score into 83.15 scores for the post-test. Questionnaires were used to know the students' comments on the speaking class using communicative approach. It can be concluded that the results of speaking class using communicative approach is proven to be effective to develop beginner respondents' ability to speak.
\end{abstract}

Keywords: communicative approach, listening class, speaking class, Japanese language

\begin{abstract}
ABSTRAK
Hasil penelitian pendahuluan yang berkaitan dengan pendekatan komunikatif pada pembelajaran bahasa menunjukkan bahwa terdapat korelasi antara kemampuan berbicara dan menulis yang keduanya merupakan kemahiran bersifat produktif, dengan menunjukkan hasil efektif dapat meningkatkan kemampuan mahasiswa dalam berbicara lebih produktif. Sehubungan dengan hal tersebut, dalam penelitian ini difokuskan antara kemampuan yang bersifat reseptif dan produktif, yakni kemampuan menyimak dan berbicara khususnya pada responden tingkat dasar awal untuk mengetahui sejauh mana kompetensi responden secara lisan. Adapun metode yang digunakan dalam penelitian ini adalah kuasi eksperimen tanpa adanya kelas kontrol. Hal ini dimaksudkan untuk mendeskripsikan proses pembelajaran dengan menggunakan pendekatan komunikatif. Responden adalah mahasiswa Jurusan sastra Jepang semester dua tahun ajaran 2013/2013. Data diambil dengan menggunakan dua cara yakni pre-test dan post-test serta angket untuk mengetahui hasil responden terhadap pembelajaran tersebut. Selanjutnya penelitian ini memperoleh bahwa responden mengalami kenaikan rata-rata kelas sebesar 16,31 point, dari nilai pre-test sebesar 66,84 menjadi 83,15 untuk nilai post-test. Untuk menguatkan hasil tes digunakan angket yakni untuk mengetahui tanggapan responden terhadap pembelajaran percakapan yang menggunakan pendekatan komunikatif. Hasil penelitian pembelajaran percakapan menggunakan pendekatan komunikatif terbukti efektif meningkatkan kemampuan berbicara responden tingkat dasar awal.
\end{abstract}

Kata kunci: pendekatan komunikatif, menyimak, berbicara, bahasa Jepang 


\section{PENDAHULUAN}

Mata kuliah Menyimak dan Percakapan terdiri dari dua keterampilan bahasa yang bersifat reseptif dan produktif. Hasil penelitian terdahulu (Supriatnoko, 1990) yang berkaitan dengan pendekatan komunikatif dalam pembelajaran bahasa menunjukkan bahwa terdapat korelasi antara kemampuan berbicara dan menulis yang keduanya merupakan kemahiran bersifat produktif. Pada jurusan Bahasa dan Budaya Jepang, kedua keterampilan berbahasa tersebut tergabung ke dalam satu mata kuliah yang tidak dipisahkan secara mandiri, namun dilaksanakan secara integratif. Percakapan merupakan salah satu komponen keterampilan berbahasa yang bersifat produktif. Keterampilan tersebut akan dapat berjalan dengan baik jika didukung dengan keterampilan yang bersifat reseptif seperti mendengar dan membaca. Percakapan yang baik tentunya harus memenuhi kaidah kebahasaan, secara struktur maupun makna, serta situasi tutur seperti pembicara, lawan bicara, tujuan, dan lain-lain.

Berdasarkan hasil pengamatan peneliti yang pernah mengampu mata kuliah Menyimak dan Percakapan II, diperlukan penambahan materi yang berbasis pada kompetensi komunikatif. Selain itu, dalam website JF Nihongo Kyouiku Standaado disebutkan tingkatan kompetensi yang merujuk pada standar bahasa setingkat CEFR yang digunakan di Eropa. Maka dari itu, salah satu indikator kompetensi lisan tingkat dasar adalah A1. Komponen tersebut adalah mampu melakukan percakapan sederhana, perlahan dan diulang-ulang, mengganti ungkapan, memberi bantuan, mampu bertanya jawab mengenai hal penting, dan dengan menggunakan topik sehari-hari. Dengan demikian, di dalam penelitian dibuat pengembangan materi dari renshuu $C$ menjadi sebuah dialog kaiwa pada tiap pertemuan guna mendukung pencapaian target kompetensi komunikatif responden. Selain itu, komponen pendukung lain diperlukan juga, seperti strategi yang berkaitan dalam proses pembelajaran yang mendukung pencapaian target pada mata kuliah Menyimak dan Percakapan II.

Tujuan penelitian ini adalah mendeskripsikan model pembelajaran yang menggunakan pendekatan komunikatif, khususnya pada mata kuliah percakapan. Hal ini dilakukan karena tolok ukur kemahiran berbicara, yang merupakan kemampuan yang bersifat produktif, sulit diukur dengan nilai. Selain itu, materi yang merujuk pada kemampuan untuk dapat berkomunikasi secara aktif dengan memberikan teknik pembelajaran dengan mengisi rumpang (prefabricated pattern) pada model percakapan. Hal ini dimaksudkan agar pembelajar dapat melakukan tindakan nyata dan terbiasa untuk menggunakan imitasi dan menghafal sebagai strategi dalam berkomunikasi lebih aktif.

\section{METODE}

Penelitian Metode penelitian ini adalah penggabungan pendekatan kualitatif dan kuantitatif. Secara kualitatif diambil untuk pendeskripsian yang penuh tentang pendekatan komunikatif. Sedangkan secara kuantitatif, data yang diperoleh akan dihitung secara statistik guna mengukur keberhasilan pendekatan komunikatif secara objektif. Jenis penelitian yang diambil adalah eksperimen, yang merupakan metode yang paling produktif untuk menjawab hipotesis dan membangun hubungan yang mengandung fenomena sebab akibat (causal-effect relationship) (Sukardi dalam Endraswara, 2009). Model eksperimen yang dipilih adalah kuasi eksperimen dengan desain pre-test dan post-test. Untuk memperkuat data, digunakan angket untuk melihat respons dan manfaat pendekatan komunikatif pada hasil belajar.

\section{HASIL DAN PEMBAHASAN}

Tiap individu pembelajar adalah unik yang tidak sama satu dengan yang lain. Oleh karena itu, di dalam proses belajar dalam kelas reguler diperlukan cara untuk mengembangkan strategi pembelajar, yaitu dengan menciptakan latihan tambahan. Agar pembelajar lebih terampil dengan aspek yang diminati, maka perlu dilakukan dorongan agar mereka dapat menemukan cara terbaik dalam belajar. Kegiatan ini dapat dimulai dengan menentukan jenis materi yang akan digunakan dan apa yang diharapkan untuk dapat dikuasai oleh pembelajar.

\section{Pendekatan Komunikatif}

Dimensi pembelajaran bahasa asing sebagai bahasa kedua, khususnya bahasa Jepang, tentunya tak lepas dari ketepatan dalam menggunakan kaidah bahasa sasaran bahasa kedua. Oleh karena itu, diperlukan suatu strategi yang tepat agar proses pembelajaran dapat berjalan baik. Salah satu metode pembelajaran yang membangun dan menggali kemampuan seseorang berbahasa asing setingkat dengan kemampuan penutur asli adalah pembelajaran dengan menggunakan pendekatan komunikatif. Strategi komunikatif menurut Canale dan Swain dalam Sukamto dan Dardjowidjoyo (2008:646) adalah penguasaan secara naluri yang dipunyai seorang penutur asli untuk menggunakan dan memahami bahasa secara wajar dalam proses berkomunikasi atau berinteraksi. Sedangkan Hymes menyebutkan penggunaan bahasa berhubungan dengan konteks sosial.

Membicarakan pembelajaran bahasa yang menggunakan pendekatan komunikatif bertujuan untuk meningkatkan kemampuan mahasiswa dalam berkomunikasi, menekankan pembinaan dan pengembangan kemampuan komunikatif mahasiswa dalam situasi keseharian. Berdasarkan tujuan tersebut maka tujuan pembelajaran bahasa diarahkan untuk (1) mengembangkan kompetensi komunikatif sehingga dapat berkomunikasi dalam berbagai situasi dan konteks dan (2) mampu mendukung dan meningkatkan kemahiran bahasa yang lain seperti menyimak, berbicara, membaca, dan menulis. Selain itu ditinjau dari segi materi hendaknya materi ajar terdiri dari (a) empat keterampilan berbahasa, (b) penggunaan fungsi bahasa yang diperlukan seperti ungkapan meminta tolong, permohonan; menjelaskan tentang aktivitas, informasi, petunjuk atau cara, pendapat, bentuk larangan, dan pengandaian, (c) penggunaan variasi bahasa baik formal ataupun nonformal, dan (d) sistem bahasa yang berupa struktur, kosakata, ejaan, dsb.

Adapun penerapan pendekatan komunikatif sepenuhnya dilakukan oleh mahasiswa itu sendiri (student centered learning). Sedangkan pengajar hanya berfungsi 
sebagai fasilitator. Dengan demikian, diharapkan siswa mampu berbicara dengan baik. Indikator penelitian adalah siswa akan mampu bercerita, menanggapi masalah, dan mengungkapkan pendapat secara lisan dengan bahasa yang runtut dan mudah dipahami.

Jessup dalam Wachidah (2004) mengungkapkan bahwa pembelajaran yang berlandaskan komunikatif mengacu pada dua prinsip. Pertama, prinsip komunikasi, yaitu kegiatan yang melibatkan komunikasi nyata mampu mengembangkan proses pembelajaran; > Kedua, prinsip tugas, yaitu kegiatan menggunakan bahasa untuk melaksanakan tugas yang mampu mengembangkan proses pembelajaran. Berdasarkan prinsip tersebut, materi pembelajaran bahasa hendaknya dapat diterapkan melalui metode permainan, simulasi, bermain peran, dan komunikasi pasangan.

Mengajar menggunakan teknik bermain peran (role play) adalah teknik mengajar yang bertujuan untuk melatih mahasiswa dalam mengembangkan kemampuan dengan melihat suatu masalah dari pandangan orang lain. Role play adalah permainan drama yang diperankan oleh dua orang atau lebih, berupa peran yang berbeda-beda, dalam suatu keadaan tertentu. Pada pembelajaran bahasa yang terdiri dari kemampuan yang bersifat reseptif dan produktif - khususnya percakapan-merupakan salah satu bentuk kemahiran yang bersifat produktif. Tolok ukur dalam menilai kemampuan lisan yakni dengan cara menggunakan role play atau biasa disebut dengan bermain peran.

Menurut Hamalik (1998:20) role play bertujuan untuk (a) belajar berbuat, yakni pembelajar melakukan peran tertentu sesuai dengan kenyataan sesungguhnya berupa mengembankan keterampilan interaktif dan reaktif, (b) belajar melalui peniruan dengan menyamakan diri sebagai pelaku dan tingkah pemeran, (c) untuk belajar melalui balikan, (d) untuk belajar melalui pengkajian, penilaian dan pengulangan.

Analisis data dilakukan untuk (1) menggambarkan proses pembelajaran dengan mengggunakan pendekatan Komunikatif pada mata kuliah Menyimak dan Percakapan II khususnya pada mata kuliah percakapan, (2) mengetahui tanggapan mahasiswa terhadap penggunaan pendekatan komunikatif pada mata kuliah Menyimak dan Percakapan II. Analisis dilakukan hasil penelitian yang dilakukan pada kurun waktu periode satu semester terhadap mahasiswa UBinus pada mata kuliah Percakapan dan Menyimak II tahun ajaran 2012/2013. Materi ajar yang digunakan selama penelitian ini sesuai dengan silabus yang terdapat di Binus maya yakni, mulai dari pelajaran 14 sampai 25, dari minggu 1 hingga minggu ke 12 . Tabel 1 merupakan rincian materi beserta target komunikasi yang diharapkan pada tiap pertemuan.

Tabel 1 Rincian Materi Ajar dan target Komunikasi

\begin{tabular}{cll}
\hline Bab & \multicolumn{1}{c}{ Tema Percakapan } & \multicolumn{1}{c}{ Target komunikasi } \\
\hline 14 & 梅田まで行ってください & dapat mengungkapkan bentuk minta tolong. \\
15 & ご家族は? & dapat mengungkapkan bentuk permohonan. \\
16 & 使い方を教えてください & $\begin{array}{l}\text { dapat mengungkapkan urutan kegiatan, cara, } \\
\text { maupun petunjuk }\end{array}$ \\
17 & どうしましたか & dapat mengungkapkan bentuk larangan \\
18 & 趣味は何ですか & dapat mengungkapkan kemampuan yang berkaitan \\
& dengan kondisi atau benda. \\
19 & ダイエットはあしたからします & dapat mengungkapkan pengalaman di masa lalu. \\
20 & 夏休みはどうするの & dapat mengungkapkan bentuk kalimat ajakan. \\
21 & 私もそう思います & dapat mengungkapkan pikiran maupun pendapat \\
& どんなアパートがいいですか & mengenai suatu hal. \\
22 & どうやって行きますか & dapat mengungkapkan suatu informasi. \\
23 & 手伝ってくれますか & dapat mengungkapkan suatu aktivitas dan \\
24 & いろいろお世話になりました & informasi. \\
25 & dapat mengungkapkan bentuk permohonan. \\
\end{tabular}


Berdasarkan hasil penelitian yang dilakukan selama satu semester, maka diperoleh grafik nilai ke-25 responden berdasarkan nilai rata-rata tiap responden pada saat pre- dan post-test, seperti pada Gambar 1.

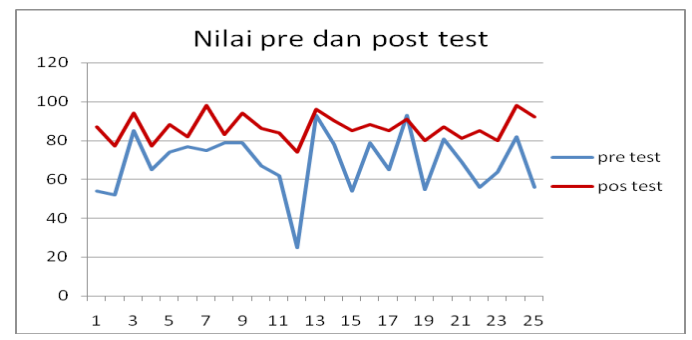

Gambar 1 Nilai Pre-test dan Post-test Responden

Jika dipersentasekan secara keseluruhan, nilai rata-rata ke-25 responden pada nilai pre-test dan post-test adalah seperti Gambar 2.

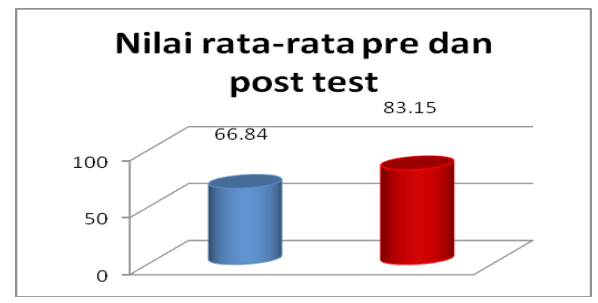

Gambar 2 Kenaikan Rata-rata Kelas pada Pre-tes dan Post-test

Gambar 2 menunjukkan kenaikan nilai rata-rata kelas sebesar 16,31 poin dari nilai pre-test sebesar 66,84 menjadi 83,15 untuk nilai post-test. Metode belajar belajar mudah dilakukan apabila memiliki metode yang mampu mengorganisasi pikiran, sikap, dan perbuatan untuk mengarahkan dan menggiatkan tahapan proses belajar secara berstruktur dan sistematis. Hal tersebut memberikan pengaruh positif bagi pembelajar itu sendiri. Responden dapat dapat menggunakan ungkapan meminta tolong, permohonan, menjelaskan tentang aktivitas, informasi, petunjuk atau cara, pendapat, bentuk larangan, dan pengandaian. Selain itu, penggunaan role play sebagai salah satu cara penilaian memiliki kelebihan dengan adanya komunikasi gap, bisa dengan formal, pemilihan ungkapan sesuai dengan situasi dan kondisi.

Hasil angket jawaban responden mengenai metode yang digunakan pada kelas Percakapan dan Menyimak dan manfaat yang diperoleh responden selama mengikuti kelas adalah pada Gambar 3.

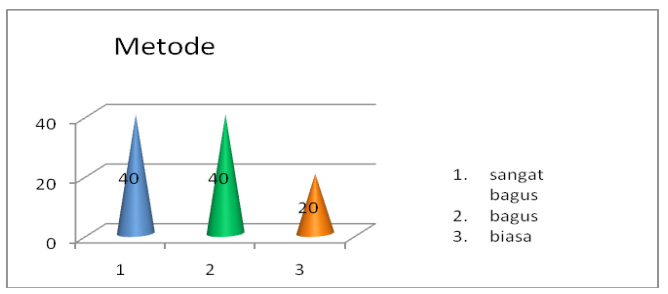

Gambar 3 Angket Jawaban Responden tentang Metode yang Digunakan
Berdasarkan hasil angket sebanyak $80 \%$ responden menyatakan metode dengan menggunakan pendekatan komunikatif yang diterapkan cukup bagus. Dengan perincian: $40 \%$ menjawab sangat bagus, $40 \%$ bagus, dan $20 \%$ menyatakan biasa saja dalam mengikuti perkuliahan percakapan II.

Selanjutnya manfaat yang diperoleh responden terbagi ke dalam kategori secara verbal dan non-verbal dapat dilihat pada Gambar 4 dan Gambar 5. Gambar 4 menunjukkan bahwa aspek verbal (bahasa) responden mengalami peningkatan mulai dari pelafalan hingga ketepatan sasaran pembicaraan sebagai berikut. Sebanyak $50,1 \%$ responden sangat terbantu dalam hal pelafalan; $16,6 \%$ penggunaan tekanan; sebesar $16,6 \%$ terlatih dalam menggunakan nada yang sesuai; $8,3 \%$ dapat menggunakan pilihan kata yang sesuai; $8,3 \%$ sesuai dengan ketepatan sasaran pembicaraan.

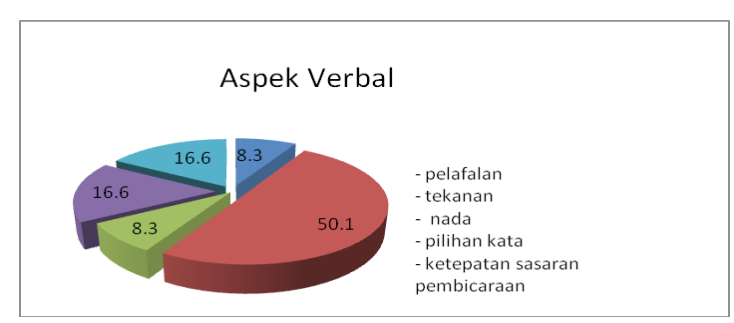

Gambar 4 Manfaat Verbal bagi Responden

Gambar 5 menunjukkan bahwa pada aspek nonverbal responden menjawab jika mereka mengalami peningkatan dalam hal penalaran hingga dapat bersuara jelas atau nyaring. Peningkatan yang paling besar berupa: 43,4\% mampu menalar dengan baik; 34,7\% terbantu dalam menguasai topik; 4,38\% mampu bersikap sesuai dengan situasi dan kondisi; 4,38\% dapat berinteraksi secara kontak mata dengan lawan bicara; 4,38\% dapat menghargai pendapat orang lain; 4,38\% mampu menempatkan gesture dengan tepat; $4,38 \%$ berani untuk bersuara jelas atau nyaring.

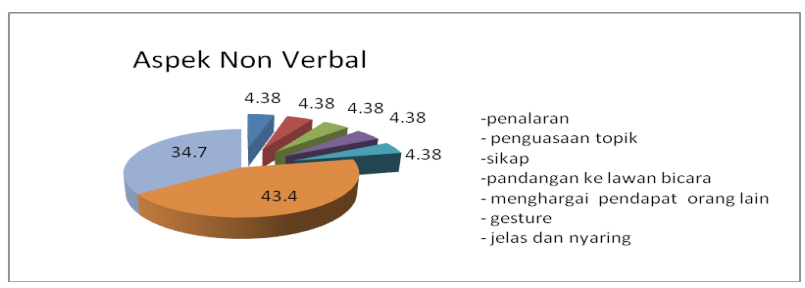

Gambar 5 Manfaat dari Aspek Non-Verbal

Hasil Model Percakapan yang telah dibuat responden selama kurun waktu satu semester yang terdiri dari hajimari, youken, dan owari dengan menggunakan pendekatan komunikatif ditunjukkan dalam Tabel 2. 
Tabel 2 Model Percakapan yang Dibuat Responden

\begin{tabular}{|c|c|c|c|c|}
\hline Bab & 始まり & 用件 & 終わり & その他 \\
\hline 14 & あのう〜さん、 & $\begin{array}{l}\text { 〜を貸してください } \\
\text { 〜を書いてください } \\
\text { 〜を手伝ってください }\end{array}$ & $\begin{array}{l}\text { お願いしますす } \\
\text { ありがとう } \\
\text { ございます }\end{array}$ & $\begin{array}{l}\text { Meminta tolong untuk } \\
\text { meminjamkan benda, } \\
\text { menuliskan, membantu }\end{array}$ \\
\hline 15 & あのう〜さん、 & $\begin{array}{l}\text { 〜をもらってもいいですか } \\
\text { 〜をみてもいいですか } \\
\text { 〜をもって行ってもいいですか } \\
\text { 〜をかりてもいいですか }\end{array}$ & 〜そうでうか & $\begin{array}{l}\text { Meminta izin meminjam } \\
\text { suatu benda }\end{array}$ \\
\hline 16 & あのう〜さん、 & $\begin{array}{l}\text { 〜を見て、〜押して、それから〜出ます } \\
\text { 〜を煮て、〜を入れて、それから出来上がります } \\
\text { 〜を決めて、〜を書いて、それから〜します } \\
\text { 〜をつけて、〜を選んで、それから〜します } \\
\text { 〜を洗って、〜をだして、それから〜します } \\
\text { 〜を押して、〜をさして、それから〜します } \\
\text { 〜を買って、〜に乗って、それから〜降ります } \\
\text { 〜を使って、〜を確認してそれから〜します } \\
\text { 〜を洗って、〜を押して、それから〜待ちます } \\
\text { 〜を入れて、〜を混ぜて、. }\end{array}$ & そうですね & $\begin{array}{l}\text { Menjelaskan urutan } \\
\text { mengoperasikan suatu alat, } \\
\text { membuat masakan, naik } \\
\text { kendaraan, }\end{array}$ \\
\hline 17 & あのう〜さん、 & $\begin{array}{l}\text { 〜を使わないでください } \\
\text { 〜を見ないでください } \\
\text { 〜 行かないでください } \\
\text { 〜をつけないでください }\end{array}$ & $\begin{array}{l}\text { はい、わかりました。ありがと } \\
\text { うございました。 }\end{array}$ & $\begin{array}{l}\text { Melarang tidak } \\
\text { memakai alat, kondisi, } \\
\text { mengoperasikan alat }\end{array}$ \\
\hline 18 & あのう〜さん、 & $\begin{array}{l}\text { 〜を弾くことができます } \\
\text { ～をすることができます } \\
\text { 〜をうたうことができます } \\
\text { 〜を撮ることができます } \\
\text { 〜踊ることができます } \\
\text { 〜を書くことができます } \\
\text { 〜を読むことができます } \\
\text { 〜を買うことができます } \\
\text { 〜を見ることができます } \\
\text { 〜インターネットができます } \\
\text { 〜を作ることができます }\end{array}$ & $\begin{array}{l}\text { ああ、すごい } \\
\text { ですね }\end{array}$ & $\begin{array}{l}\text { Menerangkan bisa atau } \\
\text { tidaknya suatu alat, benda }\end{array}$ \\
\hline 19 & あのう〜さん、 & $\begin{array}{l}\text { 〜を食べたことがあります } \\
\text { 〜したことがあります } \\
\text { 〜を見たことがあります } \\
\text { 〜 乗ったことがあります } \\
\text { 〜で泳いだことがあります } \\
\text { 〜やってみたことがあります } \\
\text { 〜行ったことがあります } \\
\text { をを作ったことがあります } \\
\text { ～踊ったことがあります }\end{array}$ & $\begin{array}{l}\text { そうですか。 } \\
\text { いいですね }\end{array}$ & $\begin{array}{l}\text { Memperoleh pengalaman } \\
\text { berkaitan dengan aktivitas, } \\
\text { tempat }\end{array}$ \\
\hline 20 & あのう〜さん、 & $\begin{array}{l}\text { 〜行かない } \\
\text { ～食べたことある } \\
\text { ～好き } \\
\text { 〜参加したい } \\
\text { 〜見ようか }\end{array}$ & $\begin{array}{l}\text { うん、またね } \\
\text { じや、また }\end{array}$ & $\begin{array}{l}\text { Menyatakan bentuk informal } \\
\text { ajakan, menceritakan } \\
\text { pengalaman/ Kegemaran/ } \\
\text { Keinginan }\end{array}$ \\
\hline 21 & あのう〜さん、 & 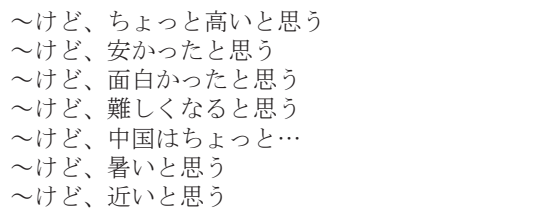 & $\begin{array}{l}\text { そうか } \\
\text { いいね }\end{array}$ & $\begin{array}{l}\text { Menyatakan ungkapan } \\
\text { berupa pikiran maupun } \\
\text { pendapat mengenai suatu hal }\end{array}$ \\
\hline 22 & あのう〜さん、 & $\begin{array}{l}\text { 〜ている人 } \\
\text { 〜するスポーツ } \\
\text { 〜買ったパソコン } \\
\text { 〜撮った写真 } \\
\text { 〜作ったセーター } \\
\text { 〜もらったかばん } \\
\text { 〜買った物 }\end{array}$ & $\begin{array}{l}\text { じゃね } \\
\text { いいね } \\
\text { どうも } \\
\text { そうですか。 } \\
\text { いいですね } \\
\text { うん } \\
\text { ありがとう } \\
\text { ございます } \\
\text { ありがとう } \\
\text { ございます }\end{array}$ & $\begin{array}{l}\text { Menyatakan ungkapan } \\
\text { berupa suatu informasi }\end{array}$ \\
\hline 23 & $\begin{array}{l}\text { 〜さん、こんにちは } \\
\text { 〜さん、おはようございます } \\
\text { あのうすみません }\end{array}$ & $\begin{array}{l}\text { ～歩くと、そこにネットカ フェがあります } \\
\text { ～押すと、チャージができます } \\
\text { ～回すと、大きくなります } \\
\text { ～曲がると、公園があります } \\
\text { ～引くと、動きますよ }\end{array}$ & $\begin{array}{l}\text { わかりました。ありがとう } \\
\text { ございます }\end{array}$ & $\begin{array}{l}\text { Menyatakan ungkapan } \\
\text { berupa suatu aktivitas dan } \\
\text { informasi }\end{array}$ \\
\hline 24 & $\begin{array}{l}\text { 〜さん、こんにちは } \\
\text { 〜さん、おはようございます }\end{array}$ & $\begin{array}{l}\text { ～手伝ってくれますから } \\
\text { 〜作ってもらいました } \\
\text { 〜作ってあげます } \\
\text { 〜つれて行ってくれました } \\
\text { 〜買ってくれました } \\
\text { 〜貸してもらいました } \\
\text { 〜ガイドしてくれました } \\
\text { 〜送ってもらいました }\end{array}$ & $\begin{array}{l}\text { ありがとうございます } \\
\text { そうですか。いいですねありが } \\
\text { とうございますそうですか。い } \\
\text { いですねありがとうございま } \\
\text { すそうですか。いいですねそ } \\
\text { うですか。 } \\
\text { いいですね }\end{array}$ & $\begin{array}{l}\text { Menyatakan ungkapan } \\
\text { permohonan }\end{array}$ \\
\hline
\end{tabular}




\section{SIMPULAN}

Berdasarkan analisis maka dapat disimpulkan bahwa kelebihan dalam penelitian dengan menggunakan pendekatan komunikatif adalah responden terbantu dalam menyelami suatu masalah; memperoleh pengalaman yang terdapat pada orang lain; bertambah rasa percaya diri sehingga dapat meningkatkan kemampuan baik secara verbal maupun non-verbal; dapat berbicara sesuai dengan target komunikasi pada tiap pertemuan yakni ungkapan meminta tolong, permohonan (menjelaskan tentang aktivitas, informasi,petunjuk atau cara,pendapat), bentuk larangan, dan pengandaian; dapat menerapkan penggunaan hajimari, youken dan owari (kalimat pembuka, isi dan kalimat penutup). Hajimari berupa 挨拶、あのうすみません、youken yakni ungkapan meminta tolong, permohonan, (menjelaskan tentang aktivitas, informasi,petunjuk atau cara,pendapat), bentuk larangan, dan pengandaian dan owari yakni 分かりまし た、ありがとうございました、そうですか、いいで すね.

Sedangkan kekurangan pada penelitian ini adalah penelitian membutuhkan banyak waktu untuk mempersiapkan materi ajar pada tiap pertemuan; pengampu mata kuliah harus memiliki ide yang luas agar materi dapat tersampaikan dengan baik; kadangkala ada kecenderungan responden ketika diberi tugas membuat percakapan dengan menggunakan kartu role play, mereka tidak senang memerankan sesuatu atau kesulitan dalam memerankan.

Beberapa hal yang perlu diperhatikan dalam penelitian adalah pertama, dengan menggunakan model percakapan pada renshuu $\mathrm{C}$ yang merupakan pola kalimat pendek, responden dapat mengembangkan menjadi model percakapan lengkap yang terdiri dari hajimari, youken, dan owari atau pembukaan, isi, dan penutup. Kedua, target komunikasi yang diharapkan pada tiap pertemuan dapat tercapai dengan baik, yakni responden dapat menggunakan ungkapan meminta tolong, permohonan, menjelaskan tentang aktivitas, informasi, petunjuk atau cara, pendapat, bentuk larangan, dan pengandaian. Ketiga, agar mendapatkan hasil maksimal, pembelajaran dengan menggunakan pendekatan komunikatif dapat diterapkan pada ketiga kemahiran bahasa yang lain, yakni mendengar, membaca, dan menulis.

\section{DAFTAR PUSTAKA}

Akito, O. (2012). Kaiwa kyouiku no shirabasu to gakushuukatsudou.Prosiding Seminar Internasional Pendidikan Bahasa Jepang, "Improving the Competence of Conversation Skill in Learning Japanese Language in Secondary and Higher Education in Indonesia". Bali, 21-22 September 2012

Endraswara, S. (2009). Metodologi Penelitian Foklor. Yogyakarta: Medpress.

Hamalik, O. (1998). Sumbangsih: Jurnal Penelitian UNS, $4(2)$.

Japan Foundation Nihongo Kyoujuhou Shirizu 6. (2007). Hanasu koto wo oshieru.Tokyo.

Japan Foundation Nihongo Kyoujuhou Shirizu 5. (2008). Kiku koto wo oshieru. Tokyo.
JF Nihongo Kyouiku Standaado. (n.d.) Kompetensi Berbahasa Jepang. Diakses dari https://jfstandard. $\mathrm{jp} / \mathrm{cando} / \mathrm{search} / \mathrm{list} / \mathrm{ja} / \mathrm{render}$.do

Sukamto, K. E. dan Dardjowidjoyo, S. (2008). Kelana Bahasa Sang Bahasawan. Jakarta: Atmajaya.

Supriatnoko. (1990). Efektifitas pendekatan komunikatif pada pengajaran bahasa Inggris terhadap kemampuan mahasiswa Politeknik UI dalam berbahasa Inggris produktif [Abstrak]. Laporan Penelitian UI. Diakses dari http://lontar.ui.ac.id/ opac/themes/libri2/abstrakpdf.jsp?id=77221

Wachidah, S. (2004). PELBBA 17: Kurikulum Berbasis Kompetensi. Jakarta: Atmajaya. 